\title{
Molecular and cellular characteristics of human and non-human primate multipotent stromal cells from the amnion and bone marrow during long term culture
}

\author{
Olena Pogozhykh¹, Denys Pogozhykh¹, Anna-Lena Neehus', Andrea Hoffmann², Rainer Blasczyk'
} and Thomas Müller ${ }^{1 *}$

\begin{abstract}
Introduction: Multipotent stromal cells (MSCs) are among the key candidates in regenerative medicine. However variety of MSC sources and general heterogeneity lead to controversial data in functional characterization. Furthermore, despite intensive usage as preclinical animal model, little is known about MSCs of the common marmoset monkey.
\end{abstract}

Methods: MSCs derived from placental amnion and bone marrow samples from human and common marmoset were characterized in parallel over 12 passages to monitor similarities and significant differences ( $p \leq 0.05$, Student's t-test) in MSC markers and major histocompatibility complex (MHC) class I expression by immunohistochemistry, flow cytometry, real-time PCR, metabolic activity test, with special focus on pluripotency associated genes.

Results: Human and non-human primate MSCs were characterized for expression of MSC markers and capability of differentiation into mesenchymal lineages. MSCs could be cultured more than 100 days (26 passages), but metabolic activity was significantly enhanced in amnion vs. bone marrow MSCs. Interestingly, MHC class I expression is significantly reduced in amnion MSCs until passage 6 in human and marmoset, but not in bone marrow cells. For MSC markers, CD73 and CD105 levels remain unchanged in amnion MSCs and slightly decline in bone marrow at late passages; CD166 is significantly higher expressed in human MSCs, CD106 significantly lower vs. marmoset. All cultured MSCs showed pluripotency marker expression like Oct-4A at passage 3 significantly decreasing over time (passages 6-12) while Nanog expression was highest in human bone marrow MSCs. Furthermore, human MSCs demonstrated the highest Sox2 levels vs. marmoset, whereas the marmoset exhibited significantly higher Lin28A values. Bisulfite sequencing of the Oct-4 promoter region displayed fewer methylations of CpG islands in the marmoset vs. human.

Conclusions: Little is known about MSC characteristics from the preclinical animal model common marmoset vs. human during long term culture. Studied human and common marmoset samples share many similar features such as most MSC markers and reduced MHC class I expression in amnion cells vs. bone marrow. Furthermore, pluripotency markers indicate in both species a subpopulation of MSCs with true 'stemness', which could explain their high proliferation capacity, though possessing differences between human and marmoset in Lin28A and Sox2 expression.

\footnotetext{
*Correspondence: mueller.thomas@mh-hannover.de

${ }^{1}$ Institute for Transfusion Medicine, Hannover Medical School,

Carl-Neuberg-Straße 1, 30625 Hannover, Germany

Full list of author information is available at the end of the article
}

(c) 2015 Pogozhykh et al. Open Access This article is distributed under the terms of the Creative Commons Attribution 4.0 International License (http://creativecommons.org/licenses/by/4.0/), which permits unrestricted use, distribution, and reproduction in any medium, provided you give appropriate credit to the original author(s) and the source, provide a link to the Creative Commons license, and indicate if changes were made. The Creative Commons Public Domain Dedication waiver (http://creativecommons.org/publicdomain/zero/1.0/) applies to the data made available in this article, unless otherwise stated. 


\section{Introduction}

Multipotent stromal cells (MSCs) are among the key candidates in the broad perspective of application in the field of regenerative medicine, tissue engineering, and cell replacement therapy. This status is determined by their relative availability from various sources, high plasticity, and immunomodulatory properties. Unlike the other promising candidates, such as embryonic stem cells (ESCs), MSCs do not face ethical and legislative issues and do not have modified genotypes, as in the induced pluripotent stem cells (iPSCs), which makes MSCs more realistic for clinical usage in the near future. Among many varying definitions, MSCs are to date defined as a class of cells with the potential to self-renew and with certain "stemness" abilities, mostly to differentiate into multiple cell lineages within the same germ layer [1]. Furthermore, MSCs display a spindle-shaped morphology, are adherent to plastic, and are positive for certain surface markers, such as $\mathrm{CD} 106^{+}, \mathrm{CD} 105^{+}, \mathrm{CD} 90$ ${ }^{+}, \mathrm{CD} 3^{+}, \mathrm{CD}^{+} 1^{+}, \mathrm{CD} 44^{+}$, and $\mathrm{CD} 29^{+}$, while being negative for hematopoietic markers, such as $\mathrm{CD}^{-}$and $\mathrm{CD} 45^{-}[2,3]$. Yet marker combinations can vary depending on the variety of sources for isolation, resulting in a broad diversity and heterogeneity of obtained cell populations. Isolation of MSCs often implies invasive procedures and mostly does not result in large-scale numbers of cells. However, stromal cells of placenta and bone marrow, obtained by natural delivery and apheresis, provide one of the most reliable and abundant sources of MSCs [4]. Probably owing to the variety of MSC sources, as well as the heterogeneity of the derived cell populations in primary cultures, many controversial results exist from different groups in terms of various functions and the general characterization of MSCs [5-7]. Some authors question the proliferation capacities of placental MSCs compared with those from bone marrow, arguing that the placenta is a temporal organ with terminated postnatal function. Nevertheless, over the last decades placental MSCs have attracted attention in the field of research as well as in clinical application, which is determined by the virtual absence of ethical concerns and ease of access [8]. Furthermore, there are divergent reports about possible culture duration of MSCs $[1,6,9]$ and changes in the expression of MSC markers and major histocompatibility complex (human leukocyte antigen (HLA)/MHC class I, which is a major obstacle in transplantation) over time [6, 10]. Lastly, the expression of pluripotency genes such as Oct-4A, Nanog, Sox2, Klf4, and $c-M y c$ in MSCs is still discussed controversially $[9,11-14]$.

To address these topics, in this study we performed a comprehensive characterization of MSCs derived from human placental amnion and bone marrow over time in culture. Parallel to the human study, we utilized cells from our animal model, a small Brazilian nonhuman primate (common marmoset monkey, Callithrix jacchus), which is readily used as a preclinical model with the possibility of mimicking numerous pathologies, including various neurodegenerative and immune-relevant diseases, which are inherent to human and other primates [15]. While ESC and iPSC lines from $C$. jacchus are well established and characterized [16-19], little is known about the marmoset MSCs, especially in comparison with such cells of a human origin.

\section{Materials and methods \\ Retrieval of tissue}

In the case of the human, three samples of bone marrow were obtained during routine surgeries at Hannover Medical School in the Department of Orthopaedic Surgery, approved by the Ethical Commission of Hannover Medical School (ethic votum No. 565-2009). Five human placentas were donated anonymized after routine Caesarian-section birth in the Department of Gynecology at Hannover Medical School, Hannover, Germany and approved by the Ethical Commission of Hannover Medical School (ethic votum No. 2396-2014). All human samples were obtained in an anonymized form with consent from the patients. In the case of the nonhuman primate model, obtaining three samples of bone marrow (post mortem) and five samples of placenta (post natal) from healthy marmosets was approved by Institutional Animal Care from the Centre of Reproductive Medicine and Andrology (CeRA), Muenster, Germany. Placenta samples were collected after natural birth at CeRA.

\section{Isolation of marmoset bone marrow stromal cells}

The bone marrow of marmoset was isolated post mortem by rupture of the tibia and femur of each animal immediately after death had been confirmed by a veterinarian. The cavity was flushed with a hypodermic needle attached to a syringe. For preventing coagulation and for cell singularization, a heparin phosphate-buffered saline (PBS) mix was utilized $(5 \mathrm{IU} / \mathrm{ml}$ ) and the bone marrow was separated by pipetting thoroughly for 3 minutes. After singularization, the cell suspension was transferred into red cell lysis buffer $\left(\mathrm{NH}_{4} \mathrm{Cl} 0.15 \mathrm{M}\right.$, $\mathrm{KHCO}_{3} 10 \mathrm{mM}$, ethylenediaminetetraacetic acid (EDTA) $0.1 \mathrm{mM}, \mathrm{pH} 7.5)$ for 5 minutes and centrifuged at $200 \times g$ for 10 minutes. The cell pellet was resuspended in the MSC culture medium consisting of Dulbecco's Modified Eagle Medium (DMEM; Biochrom AG, Berlin, Germany), $15 \%$ fetal calf serum (FCS; Biochrom AG), 1 \% penicillin/ streptomycin (Invitrogen $\mathrm{GmbH}$, Karlsruhe, Germany), and $50 \mu \mathrm{M}$ L-ascorbic acid-2-phosphate and plated on a cell culture dish (Greiner Bio-One $\mathrm{GmbH}$, Frickenhausen, Germany). 


\section{Isolation of human bone marrow stromal cells}

Bone marrow aspirates were obtained by iliac crest aspiration during routine orthopedic procedures from three healthy donors. Human MSCs were isolated from fresh heparinized bone marrow aspirates by density gradient centrifugation and subsequent recovery of mononuclear cells. Cells were washed with PBS, then resuspended in MSC medium (DMEM; Biochrom AG), $10 \%$ FCS Hyclone (Thermo Fisher Scientific, Schwerte, Germany), $1 \%$ penicillin/streptomycin (Biochrom AG), and $2 \mathrm{ng} / \mathrm{ml}$ human recombinant fibroblast growth factor (FGF)-2 (PeproTech GmBH, Hamburg, Germany) and cultured at $37{ }^{\circ} \mathrm{C}$ with $5 \% \mathrm{CO}_{2}$ at $85 \%$ humidity. Plastic-adherent cells were propagated as described previously [20].

\section{Cell isolation from placenta}

Amnion membranes were washed with PBS with $10 \%$ Ciprofloxacin (Fresenius Kabi, Bad Homburg, Germany), cut into small pieces, and incubated in the presence of $0.25 \%$ trypsin for 1 hour at $37{ }^{\circ} \mathrm{C}$. After trypsin digestion, samples were filtered through $100 \mu \mathrm{m}$ cell strainer (BD Biosciences, Durhan, NC, USA), the cell suspension was centrifuged for 5 minutes at $300 \times g$ (Heraeus Multifuge 1S-R; Thermo Fisher Scientific), and the cell pellet was resuspended in MSC growth medium and plated into $10 \mathrm{~cm}$ cell dishes (Cellstar; Greiner Bio-One $\mathrm{GmbH})$. All cell samples were tested for mycoplasma contamination. With regard to the monoplacental nature of pregnancy, amniotic membranes from the marmoset were retrieved exactly around each umbilical cord to avoid a mixture of cells from different fetuses.

\section{Flow cytometry}

After trypsinization and fixation in $4 \%$ paraformaldehyde, cells were aliquoted into fluorescence-activated cell sorting (FACS) tubes and stained with antibodies. Cells incubated with secondary antibody were used as controls. Cells were incubated at room temperature with primary and secondary antibody for 1 hour respectively. After each step, cells were washed twice in PBS and then measured with a flow cytometer (FACSCalibur ${ }^{\mathrm{Tm}}$; Becton Dickinson GmbH, Heidelberg, Germany) with a rate of 10,000 events per measurement. Cells incubated only with a secondary antibody were used as a negative control. BD CellQuest ${ }^{\mathrm{TM}}$ Pro software (version 6.0; Becton Dickinson $\mathrm{GmbH}$ ) was used for analysis of the data with a regional statistics approach.

\section{Antibodies}

Information on primary and secondary antibodies used for flow cytometry and immunohistochemistry (IHC) experiments is presented in Table 1.
Table 1 Antibodies used with corresponding working dilutions

\begin{tabular}{llll} 
and origin & & & \\
\hline CD antigen & Company & $\begin{array}{l}\text { Catalogue } \\
\text { number }\end{array}$ & Dilution \\
\hline Brachyury & Abcam (Cambridge, UK) & ab20680 & $1: 100$ \\
CD90 & Abcam (Cambridge, UK) & MRC OX-7 & $1: 100$ \\
& ab225 & \\
CD105 & Dianova (Hamburg, & DLN-07243 & $1: 100$ \\
& Germany) & & \\
CD73 & Abcam (Cambridge, UK) & 7G2 ab54217 & $1: 250$ \\
CD 34 & Beckman Coulter (Brea, & PN IM1167 & $1: 50$ \\
& CA, USA) & \\
Snail1 & Santa Cruz (Dallas, TX, USA) & SC-28199 & $1: 100$ \\
$\begin{array}{l}\text { MHC class 1 } \\
\begin{array}{l}\text { Secondary } \\
\text { antibodies }\end{array}\end{array}$ & AbDSerotec (Kidlington, UK) & MCA81 & $1: 100$ \\
$\begin{array}{l}\text { DyLight 488 donkey } \\
\text { anti-mouse lgG }\end{array}$ & Dianova (Hamburg, & 91518 & $1: 400$ \\
$\begin{array}{l}\text { DyLight 549 donkey } \\
\text { anti-mouse lgG A }\end{array}$ & Dianova (Hamburg, & 88693 & $1: 400$ \\
\hline
\end{tabular}

MHC, major histocompatibility complex

\section{Immunohistochemical staining}

For IHC staining, the Dako LSAB+System-HRP kit was used (Dako North America, Carpinteria, CA, USA). For the examination for mesenchymal markers, $2 \times 10^{4}$ cells/well of each sample were seeded on a glass slide (20 $\mathrm{mm}$ in diameter) in a 12 -well plate (Greiner BioOne $\mathrm{GmbH}$ ) and then fixed with $4 \%$ paraformaldehyde after 24 hours. After washing in PBS, six drops of $3 \%$ hydrogen peroxide were added to each well for $5 \mathrm{mi}$ nutes to block endogenous peroxidase activities. The cells were incubated with respective biotinylated antibody overnight at $4{ }^{\circ} \mathrm{C}$. The link solution was then applied to the glass slides for 30 minutes followed by streptavidin peroxidase for 30 minutes. The substrate solution was added to each well and incubated for 7-15 minutes until positive signals were visible on the glass slides. Then cells were washed twice with $1 \mathrm{ml}$ distilled water. For a nuclei counterstaining, $300 \mu$ l hematoxylin were added and incubated for 3-5 minutes. After a last washing step with distilled water, the glass slides were transferred upside down onto an object plate in one drop of Mowiol $^{\circledR}$ 4-88 (Sigma-Aldrich GmbH, Seelze, Germany) and dried overnight in the dark. Images were taken using a Keyence Biozero microscope (Keyence Germany GmbH, Neu-Isenburg, Germany).

\section{Total RNA isolation and RT-PCR}

RNA was extracted using the peqGOLD Total RNA Kit (Peqlab GmbH, Erlangen, Germany). Briefly, after trypsinization the pellet was lysed in $400 \mu \mathrm{l}$ RNA lysis buffer and transferred to a DNA removing column to remove contaminant DNA. After centrifugation at $12,000 \times g$ for 
1 minute, $400 \mu \mathrm{l}$ of $70 \%$ ethanol was added to the flowthrough. The lysate was loaded onto a Perfect Bind RNA Column and centrifuged at $10,000 \times g$ for 1 minute to bind the RNA to the column. After a washing step with $500 \mu \mathrm{l}$ RNA Wash Buffer I and washing twice with $600 \mu \mathrm{l}$ RNA Wash Buffer II, the column was dried by centrifugation at $10,000 \times g$ for 2 minutes. Finally, the RNA was eluted from the column by applying $50 \mu$ l sterile RNase-free $\mathrm{dH}_{2} \mathrm{O}$. The RNA concentration was measured with a NanoDrop photometer ND-1000 (Thermo Scientific, Waltham, MA, USA). Extracted RNA was transcribed into cDNA using the High Capacity cDNA Reverse Transcription Kit (Life Technologies GmbH, Darmstadt, Germany). By adding Oligo(dT) primers (TIB Molbiol, Berlin, Germany) only the mRNA was transcribed. For the analysis of the mesenchymal markers and immunorelevant molecules, a PCR reaction of

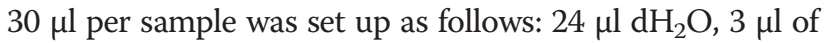
$1 \times$ PCR buffer (NEB, Frankfurt, Germany), 0.5 Units Taq polymerase (NEB), $100 \mathrm{mM}$ dNTPs (Fermentas, St. LeonRot, Germany), $20 \mathrm{pmol} / \mu \mathrm{l}$ each primer, and $1 \mu \mathrm{g}$ cDNA. Cycling conditions contained a precycling step at $95{ }^{\circ} \mathrm{C}$ for 3 minutes followed by 35 cycles of denaturation at $95{ }^{\circ} \mathrm{C}$ for 45 seconds, annealing at each corresponding primer temperature for 45 seconds, and extension at $72{ }^{\circ} \mathrm{C}$ for 90 seconds, with a final extension step at $72{ }^{\circ} \mathrm{C}$ for $10 \mathrm{mi}-$ nutes. In order to verify the product identity of the obtained cDNA fragments of the expected size, the sequencing performed in house utilizing a BigDye ${ }^{\mathrm{Tm}}$ Terminator Cycle Sequencing Ready Reaction Kit (v1.1; PE Applied Biosystems, Waltham, MA, USA) according to the manufacturer's instructions in 96-well PCR plates (Kisker, Steinfurt, Germany) in a C1000 Thermal Cycler (BioRad, Munich, Germany). A summary of oligonucleotide sequences, fragment sizes, and PCR conditions is presented in Table 2.

\section{Real-time PCR}

A $1 \mu \mathrm{l}$ sample containing $10 \mathrm{ng}$ cDNA was added to $19 \mu \mathrm{l}$ SYBR Green master mix (Life Technologies GmbH) supplemented with respective forward and reverse primer concentrations optimized by prior titration and melting curve analysis for specificity and efficiency in triplicates. The quantitative PCR was performed using a StepOnePlus real-time platform (Life Technologies $\mathrm{GmbH}$ ). Cycling conditions contained a precycling step at $95{ }^{\circ} \mathrm{C}$ for $10 \mathrm{mi}$ nutes followed by 40 cycles of denaturation at $95^{\circ} \mathrm{C}$ for 15 seconds and annealing at $60^{\circ} \mathrm{C}$ for 1 minute. Additionally, melting curves were analyzed for the specificity of the products. In cluster comparison with other housekeeper genes, ribosomal housekeeper gene RPS29 was stable in our cells and tissues, and was therefore utilized for $\Delta \mathrm{Ct}$ normalization with additional control tissue skin for
$2^{-\Delta \Delta \mathrm{Ct}}$ analysis. Oligonucleotides were designed from a consensus sequence from human and marmoset utilizing the databases from the National Center for Biotechnology Information (NCBI) and the Wellcome Trust Sanger Institute/The European Bioinformatics Institute (Ensembl). Whenever possible, sequences from two different exons were used to exclude gDNA contaminations (Table 2).

\section{Cell proliferation assay (MTT test)}

To evaluate the metabolic activity of human and marmoset MSCs through numerous passages in culture, we applied the Promega CellTiter $96^{\circ}$ Non-Radioactive Cell Proliferation Assay (Promega, Madison, WI, USA). The cellular reduction of 3-(4.5-dimethylthiazol-2-yl)-2.5-diphenyltetrazoliumbromide (MTT) into formazan crystals is catalyzed by the mitochondria of living cells and is widely accepted as a marker for the growth and metabolic activity. The assay was performed according to the manufacturer's specifications. In brief, $5 \times 10^{5}$ cells of primary culture were seeded into $10 \mathrm{~cm}$ culture dishes and cultivated for 4 days until confluence with following repassaging. After each passage, cells were seeded at a density of $1 \times 10^{4} \mathrm{MSCs} /$ well of a 96-well plate (four parallels for each sample) and cultivated for 24 hours in $100 \mu \mathrm{l} \mathrm{MSC}$ medium $\left(37^{\circ} \mathrm{C}, 5 \% \mathrm{CO}_{2}\right)$. After 24 -hour incubation, $15 \mu \mathrm{l}$ MTT reagent per well were added, incubated for 4 hours at $37{ }^{\circ} \mathrm{C}$, and then $100 \mu \mathrm{l}$ Stop Mix reagent was added to each well and incubated for 1 hour at room temperature in the absence of light. Afterwards, the formazan concentration was measured at $550-620 \mathrm{~nm}$ with an ELISA plate reader (BioRad 680 ). We compared the proliferation activities of all studied cell types with each other. The NIH 3T3 fibroblast immortal cell line was used as a control with a constant proliferation activity.

\section{Bisulfite sequencing assay}

Evaluation of the methylation status of Oct-3/4 promoter was performed by the bisulfite conversion method as described previously [21]. In brief, bisulfite treatment of genomic DNA converts unmethylated cytosines into uracil; respective changes were detected by PCR amplification followed by DNA sequencing.

Genomic DNA was produced with the peqGOLD Tissue DNA Kit (Peqlab BmbH) according to the manufacturer's protocol, from which $200 \mathrm{ng}$ were bisulfite converted with the EZ DNA Methylation-Direct ${ }^{\text {sm }}$ Kit (Zymo Research, Freiburg, Germany). The fragment of interest was amplified from converted DNA by RT-PCR using ZymoTaq ${ }^{\text {Tw }}$ PreMix (Zymo Research), with oligonucleotides published previously [21]. Respective fragments were extracted from a $1.5 \%$ agarose gel, ligated into pGEM-T Vector (Promega) and transformed into JM109 bacteria (Promega). Forty single-bacterium colonies of 
Table 2 Oligonucleotides with corresponding accession numbers

\begin{tabular}{|c|c|c|c|c|}
\hline Gene & Sequence & Annealing temperature $\left({ }^{\circ} \mathrm{C}\right)$ & Fragment size (base pairs) & Accession number \\
\hline \multirow[t]{2}{*}{ RPS29 } & 5'-CGA AAA TTC GGC CAG GGT TC-3' & 60 & 109 & XM_009006002.1 \\
\hline & 5'-TCG CGT ACT GAC GGA AAC AC-3' & & & \\
\hline \multirow[t]{2}{*}{ CD 90} & 5'-TCC CAG AAC GTC ACT GTG CT-3' & 60 & 134 & ENSCJAT00000027416 \\
\hline & 5'-AGG GAT ATG AAA TCC GTG GC-3' & & & \\
\hline \multirow[t]{2}{*}{ CD 44} & 5'-TGG CCT TGG CTT TGA TTC TT-3' & 60 & 73 & ENSG00000026508 \\
\hline & 5'-AGC TTा TTC TTC TGC CCA CA-3' & & & \\
\hline \multirow[t]{2}{*}{ CD 106} & 5'-TGG ATT CTG TGC CCA CAG AAA-3' & 60 & 120 & ENSCJAT00000006643 \\
\hline & 5'-TGG TCA CAG AGC CAC CTा CT-3' & & & \\
\hline \multirow[t]{2}{*}{ CD 166} & 5'-ACG TGT TTG AGG CAC CTA CAA-3' & 60 & 94 & ENSG00000170017 \\
\hline & 5'-AGC TGC TCT GTT TCG AGA AAT A-3' & & & \\
\hline \multirow[t]{2}{*}{$\beta 2 m$} & 5'-CGA GAT GGC TAG CTC CGT G-3' & 60 & 162 & XM_002753411.2 \\
\hline & 5'-GAT GGA TGA AAC CCA GAC AC-3' & & & \\
\hline \multirow[t]{2}{*}{ Oct 4 hs } & 5'-GGG TGG AGA GCA ACT CCG A-3' & 60 & 123 & NM_002701.5 \\
\hline & 5'-GCA GAG CTT TGA TGT CCT GGG-3' & & & \\
\hline \multirow[t]{2}{*}{ Oct $4 \mathrm{cj}$} & 5'-GGG TGG AGA GCA ATT CCG A-3' & 60 & 123 & JQ627833 \\
\hline & 5'-GCA GAG CTT TGA TGT CTT GGG-3' & & & \\
\hline \multirow[t]{2}{*}{ Sox 2} & 5'-ACA TGA ACG GCT GGA GCA A-3' & 60 & 197 & XM_002807565 \\
\hline & 5'-GTA GGA CAT GCT GTA GGT GGG-3' & & & \\
\hline \multirow[t]{2}{*}{ Nanog } & 5'-AGC TGT GTG TAC TCA ATG AT-3' & 60 & 121 & ENSCJAT00000037278 \\
\hline & 5'-TGG TTC TGG AAC CAG GTC TT-3' & & & \\
\hline \multirow[t]{2}{*}{ c-Myc } & 5'-AGC GAC TCT GAG GAG GAA CA-3' & 60 & 150 & XM_002759229 \\
\hline & 5'-GCA CCT CTT GAG GAC CAG TG-3' & & & \\
\hline \multirow[t]{2}{*}{$\operatorname{Lin} 28$} & 5'-AGT GGT TCA ACG TGC GCA T-3' & 60 & 181 & XM_002751258 \\
\hline & 5'-TCC AGA CCC TTG GCT GAC TT-3' & & & \\
\hline \multirow[t]{2}{*}{ Klf 4} & 5'-TTA ATG AGG CAG CCA CCT GG-3' & 60 & 145 & XM_002806507 \\
\hline & 5'-AAG TCG CTT CAT GTG GGA GAG-3' & & & \\
\hline
\end{tabular}

each sample were chosen; isolated plasmid DNA was submitted for sequencing (Eurofins Genomics, Ebersberg, Germany) and the obtained sequence was compared with unconverted genomic DNA with application of SnapGene software (GSL Biotech LLC, Chicago, IL, USA).

\section{Multilineage differentiation assays}

The differentiation of MSCs into adipogenic, chondrogenic, and osteogenic lineages was performed by culturing cells in specialized culture media. In brief, all studied MSC samples were seeded with concentration of $5 \times 10^{4}$ cells/well onto six-well culture dishes (Cellstar; Greiner Bio-One $\mathrm{GmbH}$ ). Adipogenic differentiation of studied MSCs was induced by culturing the cells for 14 days in medium containing $1 \mu \mathrm{M}$ dexamethasone (Sigma-Aldrich, St. Louis, MO, USA), $60 \mu \mathrm{M}$ indomethacin (Sigma-Aldrich), $0.5 \mathrm{mM}$ 3-isobutyl-1-methylxanthin (Sigma-Aldrich), $1 \%(\mathrm{v} / \mathrm{v})$ penicillin/streptomycin (Biochrom AG), and $10 \mu \mathrm{g} / \mathrm{ml}$ insulin (Sigma-Aldrich) in DMEM (Biochrom AG) supplemented with $20 \mathrm{mM}$
HEPES zwitterionic buffer (Biochrom AG) and $20 \%$ FCS HyClone $^{\mathrm{Tm}}$ (Thermo Fisher Scientific). After culturing the cells for 14 days, formation of lipid vacuoles was evaluated with Oil Red $\mathrm{O}$ staining. In brief, the cells were washed with PBS, fixed in $10 \%$ formalin (SigmaAldrich) for 20 minutes, and rinsed twice with water followed by one final wash with $50 \%$ ethanol (AppliChem $\mathrm{GmbH}$, Darmstadt, Germany). Formed lipid vacuoles were detected by incubation for 10 minutes in Oil Red O (Sigma-Aldrich) in acetone/50 \% ethanol (Merck KGaA, Darmstadt, Germany) and a final rinse with water. Adipogenic differentiation procedures for each sample were performed in triplicate and compared with undifferentiated cell control $(n=3)$ and visualized with a bright-field microscope (Keyence Biozero; Keyence, Osaka, Japan).

Osteogenic differentiation was performed by culturing cells for 21 days in medium containing $0.1 \mu \mathrm{M}$ dexamethasone, $0.05 \mathrm{mM}$ L-ascorbic acid-2-phosphate (Sigma-Aldrich), $1 \%$ (v/v) penicillin/streptomycin, and 3 
mM sodium dihydrogen phosphate monohydrate (Carl Roth GmbH, Karlsruhe, Germany) in DMEM LG (Biochrom AG) supplemented with 20 mM HEPES zwitterionic buffer and $10 \%$ FCS HyClone ${ }^{\mathrm{TM}}$. After culturing the cells for 21 days, mineralization of MSCs differentiated into osteoblasts was detected by Von Kossa staining. In brief, mineralized cells were washed twice with PBS and fixed with $10 \%$ formalin, and then washed once with PBS and twice with double-distilled water $\left(\mathrm{ddH}_{2} \mathrm{O}\right)$ followed by addition of $1 \%$ silver nitrate (Riedel de Haen $\mathrm{GmbH}$, Seelze, Germany). After that, the plate was exposed for 30 minutes to sunlight, washed with $\mathrm{dd}_{2} \mathrm{O}$, stained with $5 \%$ sodium thiosulfate (Sigma-Aldrich) for 5 minutes, and rinsed again with $\mathrm{dd}_{2} \mathrm{O}$. Osteogenic differentiation procedures for each sample were performed in triplicate and compared with undifferentiated cell control $(n=3)$ and visualized with a bright-field microscope (Keyence Biozero).

For chondrogenic differentiation, $2.5 \times 10^{5}$ cells/well were pelleted in V-shape 96-well plates (Cellstar; Greiner Bio-One $\mathrm{Gmbh}$ ) by centrifugation at $200 \times g$ for $5 \mathrm{mi}$ nutes. The pellet was incubated for 21 days in chondrogenic differentiation medium composed of DMEM HG culture medium ((Biochrom AG) supplemented with 20 mM HEPES buffer with addition of $1 \%(\mathrm{v} / \mathrm{v})$ penicillin/ streptomycin, $0.1 \mu \mathrm{M}$ dexamethasone, $1 \%$ (v/v) ITS Universal Cell Culture Supplement Premix (Becton Dickinson $\mathrm{GmbH}$ ), $0.17 \mathrm{mM}$ L-ascorbin acid-2-phosphate (SigmaAldrich), $1 \mathrm{mM}$ sodium pyruvate (Biochrom AG), 0.35 mM L-proline (Biochrom AG), and $10 \mathrm{ng} / \mathrm{ml}$ transforming growth factor- $\beta 3$ (PeproTech $\mathrm{GmbH}$ ). The medium was changed every 3 days. After 3 weeks, the pellet was fixed with $10 \%$ paraformaldehyde (Carl Roth $\mathrm{GmbH}$ ), sectioned at $7 \mu \mathrm{m}$, and stained with Alcian blue (SigmaAldrich) as an indicator of sulfated glycosaminoglycan (sGAG)-rich extracellular matrix.

\section{Statistical analysis}

Statistical analysis was conducted utilizing Microsoft Excel $^{\circledR}$ 2010. Student's $t$ test was applied for comparing complete groups with $p \leq 0.05$ values considered as statistically significant.

\section{Results}

\section{Morphology and immunohistochemistry}

After three passages following the retrieval of primary culture, all of the cells displayed a typical adherent spindle-shaped fibroblast-like morphology forming a monolayer. Interestingly, in amnion samples of both species, some colony-like spots of high cellular density were observed. The antibodies against human antigens also reacted with marmoset samples in immunohistochemical staining displaying $\mathrm{CD}^{+} 0^{+}, \mathrm{CD}_{105}{ }^{+}, \mathrm{Snail1}^{+}$, and $\mathrm{Bra}^{+}$, but CD34- (Fig. 1a-j).

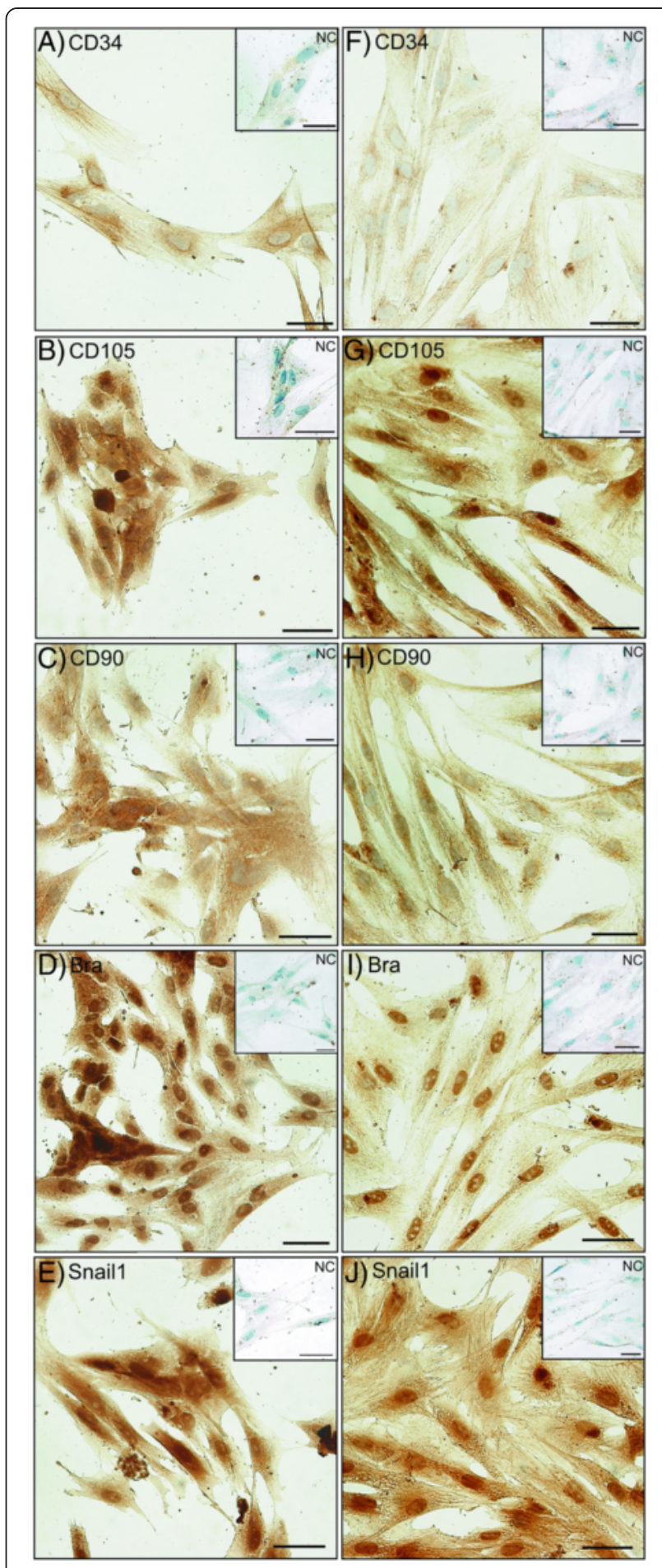

Fig. 1 Typical MSC markers were detected in marmoset and human amnion MSCs. a-e Marmoset. $\mathbf{f}-\mathbf{j}$ Human. Immunohistochemically negative signal for CD34 ${ }^{-}$, but positive signal for $\mathrm{CD}_{105}{ }^{+}, \mathrm{CD}^{+}{ }^{+}, \mathrm{Bra}^{+}$, and Snail $1^{+}$. NC absence of primary antibody

\section{Cellular proliferation capacity}

When determining cellular viability and proliferation capacity via the MTT test, amnion MSCs from both 


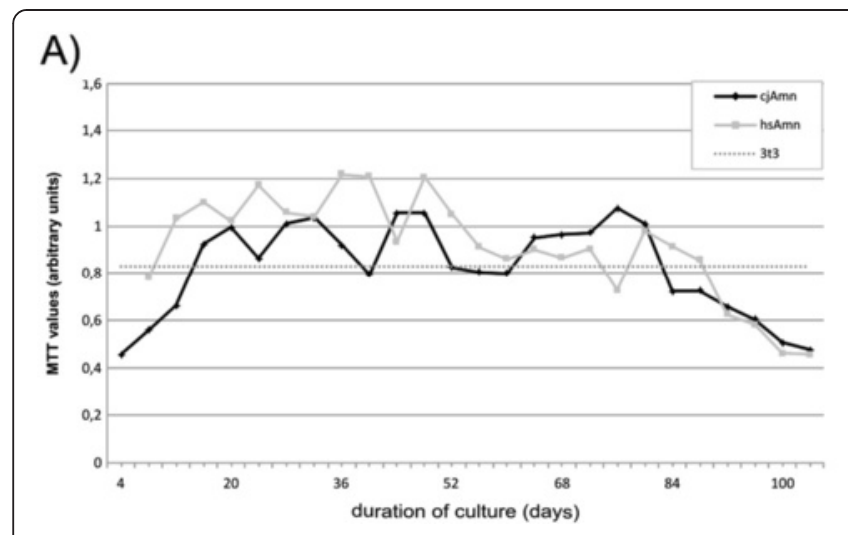

B)

Fig. 2 Evaluation of growth and metabolic activity of human and marmoset amnion and bone marrow-derived MSCs by the MTT test. Amnion-derived cells from both species have significantly higher proliferation potential $(p=0.0133)$ in long-term culture, whereas human bone marrow MSCs could not be expanded after day 60. MTT 3-(4,5-dimethylthiazol-2-yl)-2,5-diphenyltetrazolium bromide. Curve legends: a cjAmn - marmoset amnion, hsAmn - human amnion, 3t3 - control 3t3 cell line; $\mathbf{b}$ cjBm - marmoset bone marrow, hsBm - human bone marrow, 3t3 - control 3t3 cell line

species performed significantly better than bone marrow MSCs $(p=0.0133$, Student's $t$ test $)$ and also notably better than the immortalized NIH 3T3 cell line (Fig. 2a) which was used as a control owing to its stable proliferative abilities. Furthermore, human bone marrow cells stopped proliferation at 60 days of culture (Fig. 2b).

\section{Surface marker analysis}

Analysis by flow cytometry (Fig. 3a) showed that the number of $\mathrm{CD}^{+} 3^{+}$cells did not significantly change in marmoset amnion and bone marrow MSCs, $70.97 \pm 0.54$ at the early passage 3 compared with $74.43 \pm 6.36$ at the late passage 12, but significantly increased in human amnion MSCs from $86.54 \pm 0.99$ at the early passages to $96.78 \pm 0.43$ at passage 12 . In human bone marrow samples, the number of $\mathrm{CD}^{+} 3^{+}$cells was $86.44 \pm 3.44$ at the early passages, significantly reducing to $67.4 \pm 5.03$ at passage 12. Furthermore, numbers of CD105-positive cells decreased significantly from passage 6 to passage 12 in the bone marrow samples of both species, from $99.26 \pm 0.25$ and $97.66 \pm 1.19$ to $83.46 \pm 0.31$ and $77.49 \pm$ 3.51 in marmoset and human, respectively. In general, the number of $\mathrm{CD}_{105^{+}}$cells in marmoset was generally significantly lower than in human during all passages.

\section{Quantitative PCR results for MSC markers and MHC class I} In quantitative PCR, CD90 mRNA expression significantly decreased in all amnion MSC preparations during passaging (in marmoset, expression at the early passages was $3.27 \pm 0.3$-fold higher than in skin fibroblast control and at the late passages was downregulated to $-2.20 \pm$ 0.44-fold; in the human, expression was $1.51 \pm 0.09$-fold at passage 3 to $-2.25 \pm 0.62$-fold at passage 12 respectively), but significantly increased in the bone marrow MSCs of both species (from $2.38 \pm 0.18$ at passage 3 to $4.56 \pm 0.03$ at passage 12 in marmoset, and from $-4.41 \pm$
1.37 at passage 3 to $3.62 \pm 0.06$ at passage 12 in human respectively) (Fig. 3b). CD44 expression remained low and stable in marmoset amnion and bone marrow MSCs and in human bone marrow MSCs (Fig. 3c), but was significantly upregulated in human amnion cells (at passage 3 expression is $14.9 \pm 2.10$-fold, at passage 6 expression is $16.15 \pm 2.20$-fold, and at passage 12 expression is $8.35 \pm$ 1.25 -fold vs. skin). Activated leukocyte cell adhesion molecule (ALCAM, CD166) levels remained stable during passaging in all studied samples except the human bone marrow, where its expression was significantly higher compared with all other samples at passage 3 , being $21.00 \pm 1.21$ (Fig. 3d). Interestingly, vascular cell adhesion molecule 1 (VCAM-1, CD106) expression was in general significantly higher in marmoset tissues vs. human. The expression level was $127.18 \pm 0.94$ at the early passages in marmoset amnion samples and 156.22 \pm 1.99 in marmoset bone marrow samples at the early passages and was downregulated respectively to $79.22 \pm 3.34$ and $82.16 \pm 4.12$ at the late passages. In contrast, even the initial expression of CD106 in the human samples at the early passages was drastically lower than in marmoset samples, being $36.32 \pm 3.05$ for amnion MSCs and $35.42 \pm$ 3.71 for bone marrow MSCs (Fig. 3e), with further reduction in later passages in amnion samples.

Interestingly, the levels of MHC class I expression (in case of the human also called HLA) at the early passages were significantly lower in the amnion samples of both species in comparison with bone marrow. Further, we detected a significant increase in positive amnion cells of both species over time by FACS analysis (from $19.42 \pm 0.43$ at passage 3 to $79.47 \pm 2.0$ at passage 12 in human, and from $31.35 \pm 0.3$ at passage 3 to $87.21 \pm 4.0$ at passage 12 in marmoset; Fig. 4a), whereas roughly $80 \%$ of bone marrow cells were positive for W6/32 antibody from the beginning at passage 


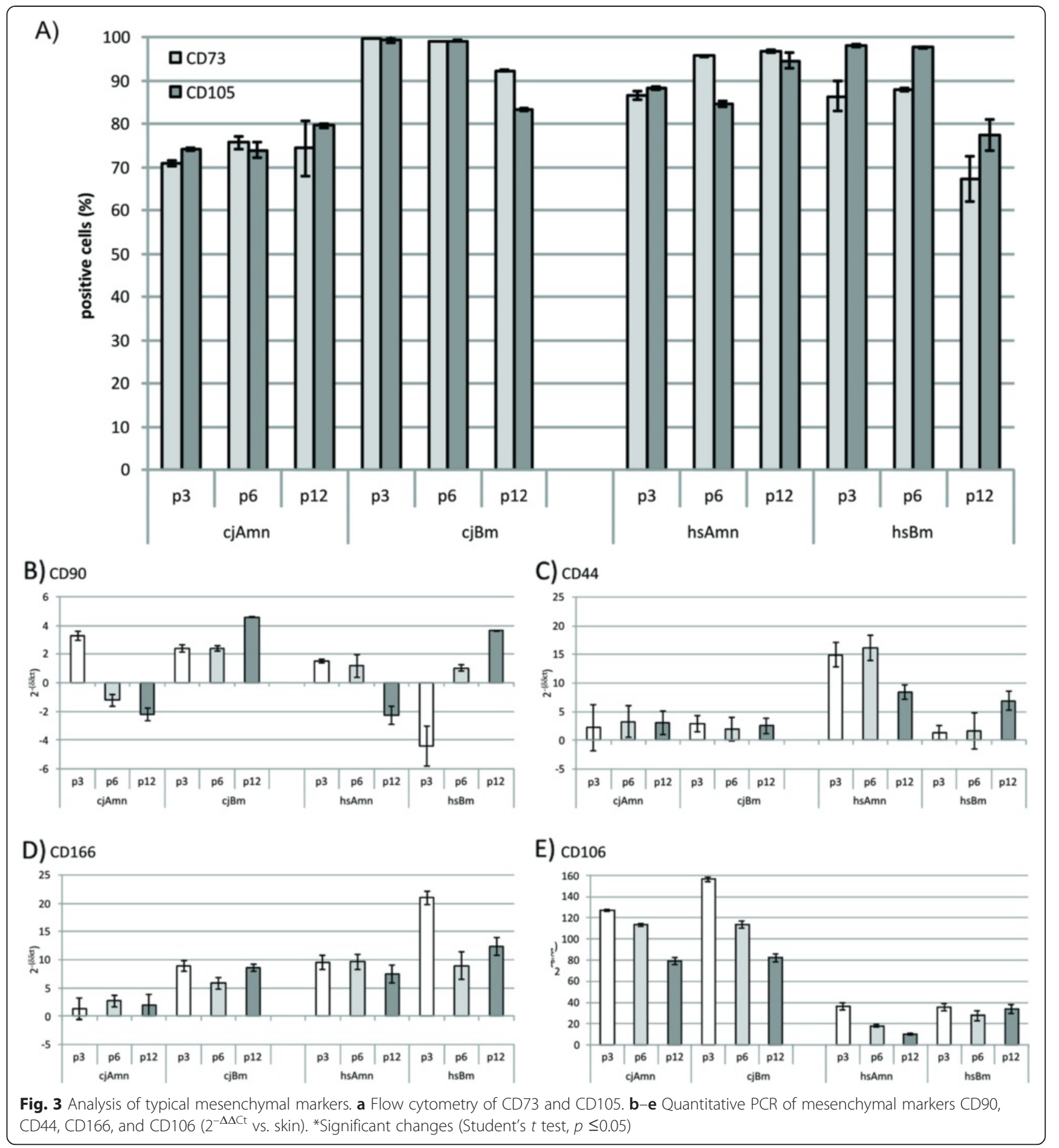

3 and remained so until passage 12 (Fig. 4a) in both species. This was in part reflected by quantitative PCR results detecting expression of beta-2-microglobulin ( $\beta 2 \mathrm{~m})$ (Fig. 4b). Here, interestingly, marmoset expressed overall significantly less $\beta 2 \mathrm{~m}$ molecules independent of tissue origin and passage when compared with human (Fig. 4b).

\section{Quantitative PCR of pluripotency genes and bisulfide} sequencing

The existence of pluripotency genes in MSCs is controversially discussed and very carefully determined by quantitative PCR for typical pluripotency genes (Fig. 5a-f); additionally, bisulfite sequencing of the Oct-4 promoter region was performed (Fig. $5 \mathrm{~g}-\mathrm{j}$ ). In our experiments, 


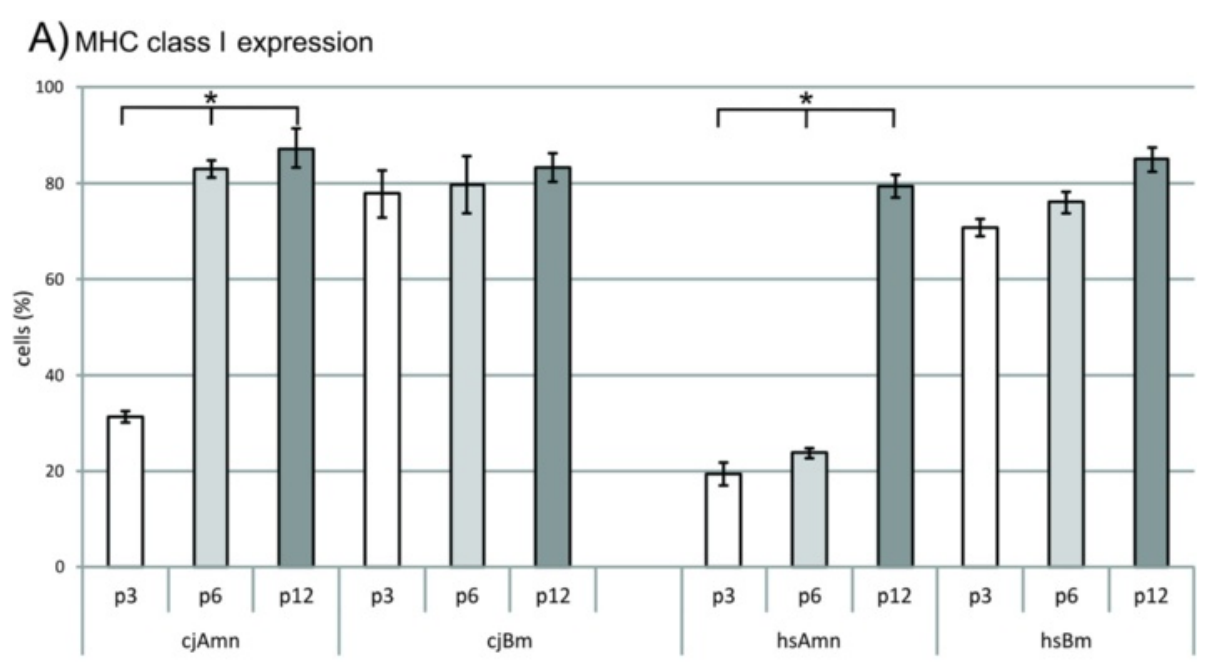

\section{B) $\beta 2 m$ expression}

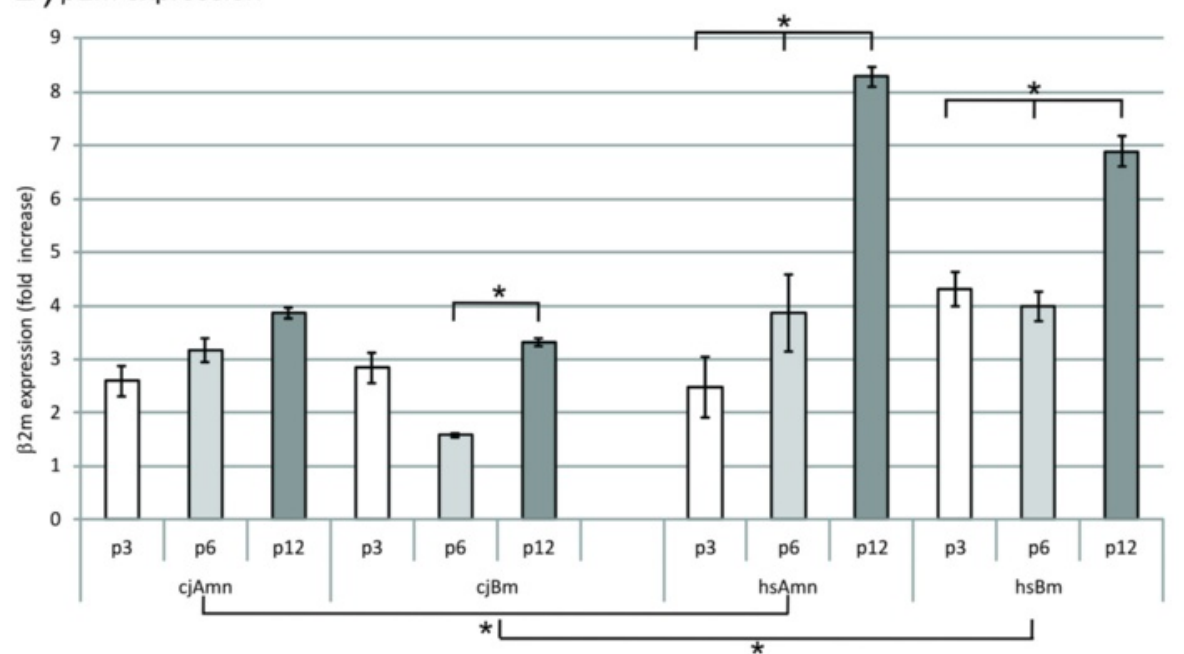

Fig. 4 Evaluation of MHC class I expression by flow cytometry $\mathbf{a}$ and $\beta 2 \mathrm{~m}$ by quantitative PCR $\mathbf{b}$ in MSCs. Amnion-derived cells from both species seem to regain immunogenicity triggered by MHC class I over time, whereas bone marrow MSCs already show full expression of MHC class I at passage 3. Interestingly, in marmoset expression of $\beta 2 \mathrm{~m}$ is significantly lower than in human. *Significance by Student's $t$ test. $\beta 2 \mathrm{~m} \beta 2$-microglobulin, MHC major histocompatibility complex

Oct-4A mRNA expression levels decreased with passaging in all cell types. In marmoset amnion, at passage 3 Oct-4A expressed $4.60 \pm 2.38$ and at passage 12 was only $1.14 \pm$ 1.92-fold higher than in the control; in human amnion, expression of Oct- $4 A$ is $9.16 \pm 1.5$ and decreases to $3.03 \pm$ 1.59 at passage 12. The levels of expression of Oct-4A in bone marrow do not differ significantly between the species. They start at passage 3 with $11.02 \pm 1.69$ and $10.71 \pm$ 1.67 and decrease at passage 12 to $1.68 \pm 1.55$ and $2.20 \pm$ 1.60 in marmoset and human respectively. Nanog expression appeared to be at stably low yet detectable levels in both species' amnion MSCs, but significantly decreased in human bone marrow MSCs from initial levels of $15.52 \pm$ 1.46 -fold vs. skin to $2.99 \pm 1.6$-fold (Fig. 5b). Interestingly,
$c-M y c$ expression was generally lower in all MSC types (Fig. 5c) than in controls (skin), although slightly upregulated at the early passages in marmoset amnion, whereas Sox2 expression was significantly lower in marmoset MSCs than in human MSCs with $27.53 \pm 1.43$-fold expression vs. skin at the early passage 3 in human amnion, $20.4 \pm 1.47$ in early passage in the bone marrow, decreasing in both types of human MSCs significantly over time to $15.01 \pm 1.57$ and $5.98 \pm 1.53$ respectively (Fig. $5 \mathrm{~d}$ ) at the late passage 12. Complementary behavior was monitored for Lin28A, which was much higher expressed in marmoset than in human. The initial level of expression of Lin28A in marmoset amnion MSCs was $15.34 \pm 1.53$-fold and was downregulated to $6.04 \pm 1.53$-fold at passage 12 ; 


\section{A) Oct4A}

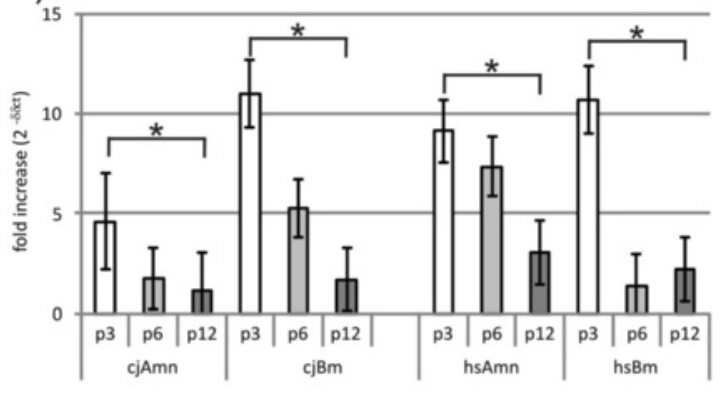

C) c-Myc

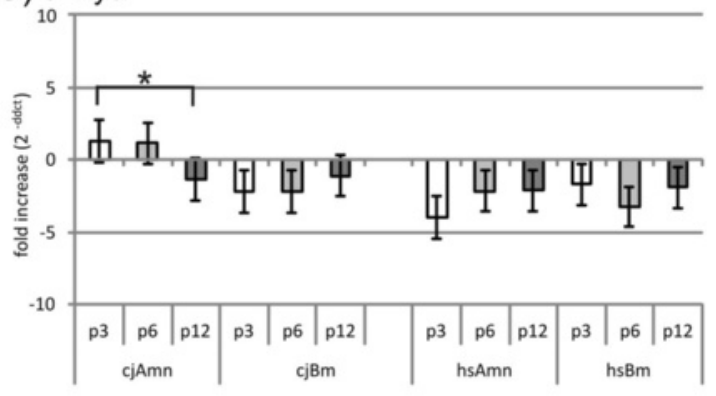

E) Lin 28

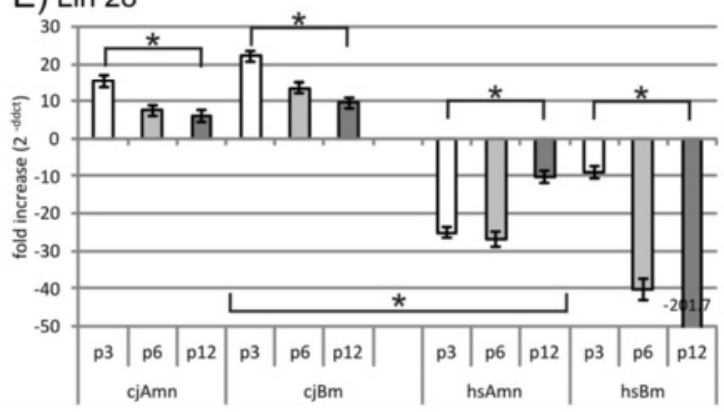

G) cjAmn

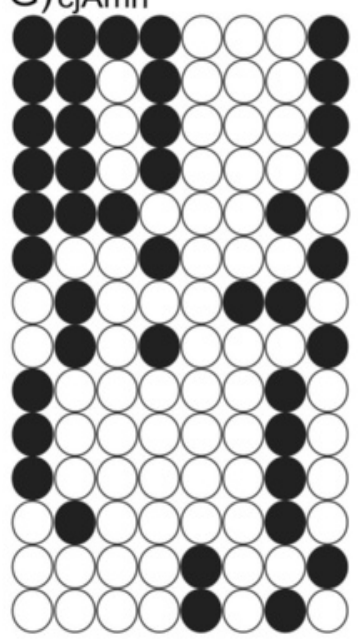

B) Nanog

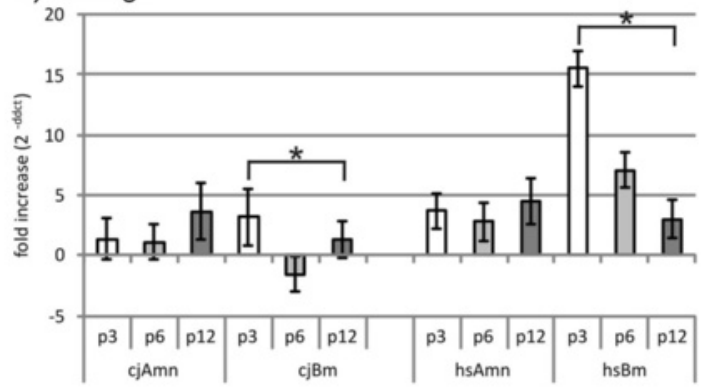

D) Sox2
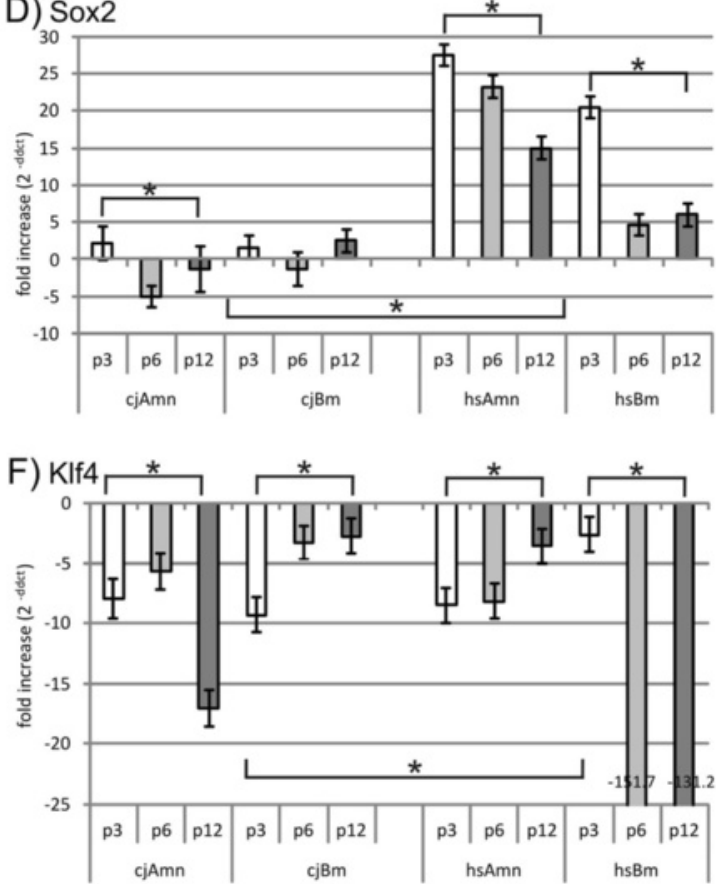

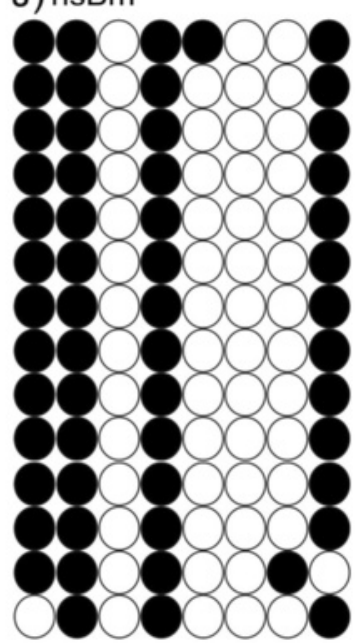

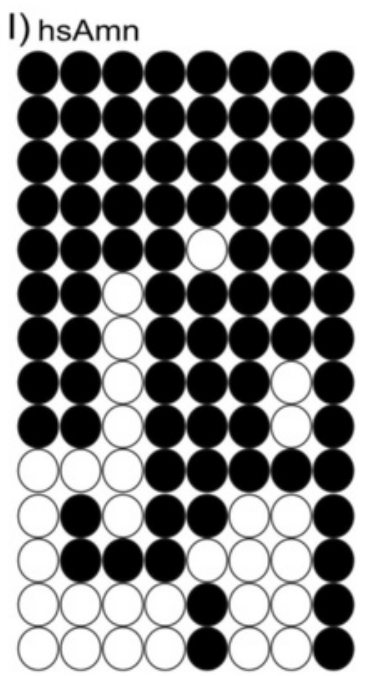

J) hsBm

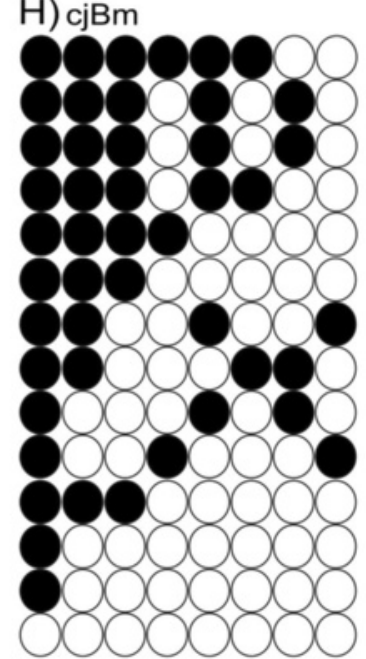

Fig. 5 (See legend on next page.) 
(See figure on previous page.)

Fig. 5 Analysis of typical pluripotency (PP) markers a-f and methylation of Oct-4 promoter $\mathbf{g}-\mathbf{j}$. Expression of PP markers could be confirmed ( $2^{-\Delta \Delta C t}$ vs. skin), primarily in early passages $\mathbf{a}, \mathbf{b}$. In general, Oct-4A represented the highest levels $\mathbf{a}$, whereas KIf4 levels were very low $\mathbf{f}$. As expected, all pluripotency marker levels decrease over time. Interestingly, marmoset tissues display significantly lower Sox2 levels vs. human f, but also significantly higher Lin28A levels e. *Significant change (Student's $t$ test). The nature of all PCR products was confirmed by DNA sequencing. Methylation analysis of the Oct-4 promoter region revealed the heterogeneity within the cell populations: marmoset amnion MSCs appeared to contain the most cells with an unmethylated pattern (open circles) $\mathbf{g}$, whereas human amnion cells contained more methylated (black circles) populations $\mathbf{i}$

in bone marrow the initial level was $22.19 \pm 1.45$ and decreased to $9.65 \pm 1.42$ during passaging. In human samples, expression of Lin28A was significantly lower than in the skin fibroblast controls. Klf4 levels were below skin controls in all cell types, further decreasing with passaging. An especially drastic decrease was observed in human bone marrow, with Klf4 mRNA $-2.61 \pm 1.43$ at passage 3 declining to $-131.18 \pm 1.45$ at passage 12 (Fig. 5f). In all MSC preparations, a partially demethylated Oct-4 promoter region could be detected (Fig. 5g-j). Marmoset MSCs showed in general fewer methylation sites than human MSCs.

\section{Differentiation experiments}

All studied samples from both species were capable of differentiation into adipogenic, osteogenic, and chondrogenic mesenchymal lineages (Fig. 6). Human bone marrow samples displayed the highest visual intensity of Alcian blue staining (Fig. 6e).

\section{Discussion}

\section{Aim of the study}

MSCs are the closest candidates for clinical application in regenerative medicine, tissue engineering, and cell replacement therapy. Their excellent availability from various sources, high plasticity, immunomodulatory properties, and genetic integrity make them an ideal cell type for clinical studies. Among these cells, bone marrow-derived, fatderived, and placental MSCs are highly attractive, owing to availability of large-scale amounts of primary cell cultures from these sources. Unfortunately, owing to the variety of MSC sources and therefore heterogeneity of the obtained MSC populations in primary cultures, results from different research groups in terms of functions and general characterization of MSCs are controversial, especially with regard to pluripotency features of MSCs. Furthermore, little is known about the differences and similarities of MSCs of the common marmoset monkey in terms of surface markers and gene expression, a readily used preclinical nonhuman primate model in comparison with human. We therefore performed a systematic study with MSCs derived from the amnion of placenta and bone marrow from both species to clarify characteristics, similarities, and differences of these cells between human and the common marmoset.

\section{Comparison of morphology and differentiation potential}

Cells from both species and both origins showed typical adherent spindle-shaped fibroblast-like morphology and were capable of differentiating into adipocytes, chondrocytes, and osteogenic direction; adipogenic potential seems to be enhanced in bone marrow vs. amnion MSCs in terms of vacuole size; and human bone marrow MSCs displayed the strongest Alcian blue staining. These observations could be explained by niche-specific differences.

\section{MSC immunohistochemistry}

All multipotent MSC lines of both species and origins possessed typical marker combinations, $\mathrm{CD} 44^{+}, \mathrm{CD}^{+} 3^{+}$, $\mathrm{CD}^{+}, \mathrm{CD}^{+} 5^{+}, \mathrm{CD} 106^{+}, \mathrm{CD} 166^{+}, \mathrm{Snail1}^{+}$, and $\mathrm{Bra}^{+}$, but $\mathrm{CD}^{-} 4^{-}$as reported by other studies [2, 22, 23]. Other groups report more $\mathrm{CD}^{+} 3^{+}$and $\mathrm{CD} 105^{+} \mathrm{MSCs}$ found in the human bone marrow (roughly $98 \%$ ) vs. approximately 10-15\% lower numbers in placenta-derived primary cultures [6], which is in accordance with our data for human and marmoset. Various groups discuss controversial results on the presence or absence of Brachyury expression [22, 24]; in our case, both species and MSC types showed positive signals in IHC.

\section{Proliferation capacities}

Our general duration of culture for amnion-derived MSCs over 120 days (26 passages) corresponds with results from other groups of 140 days with $36.9 \pm 4.7$ population doublings [24], and human placenta-derived MSCs have higher ex vivo proliferative capacity compared with human bone marrow $[6,25]$. This is interesting from a biological point of view: the placenta itself is a temporary organ, which completed its physiological function at the moment of MSC isolation, but in our case the bone marrow MSCs ceased proliferation after day 60 in human. It could be speculated that such proliferation capacity in both species is derermined by the importance of placental functions for maintenance and development of the embryo in case of injuries. 


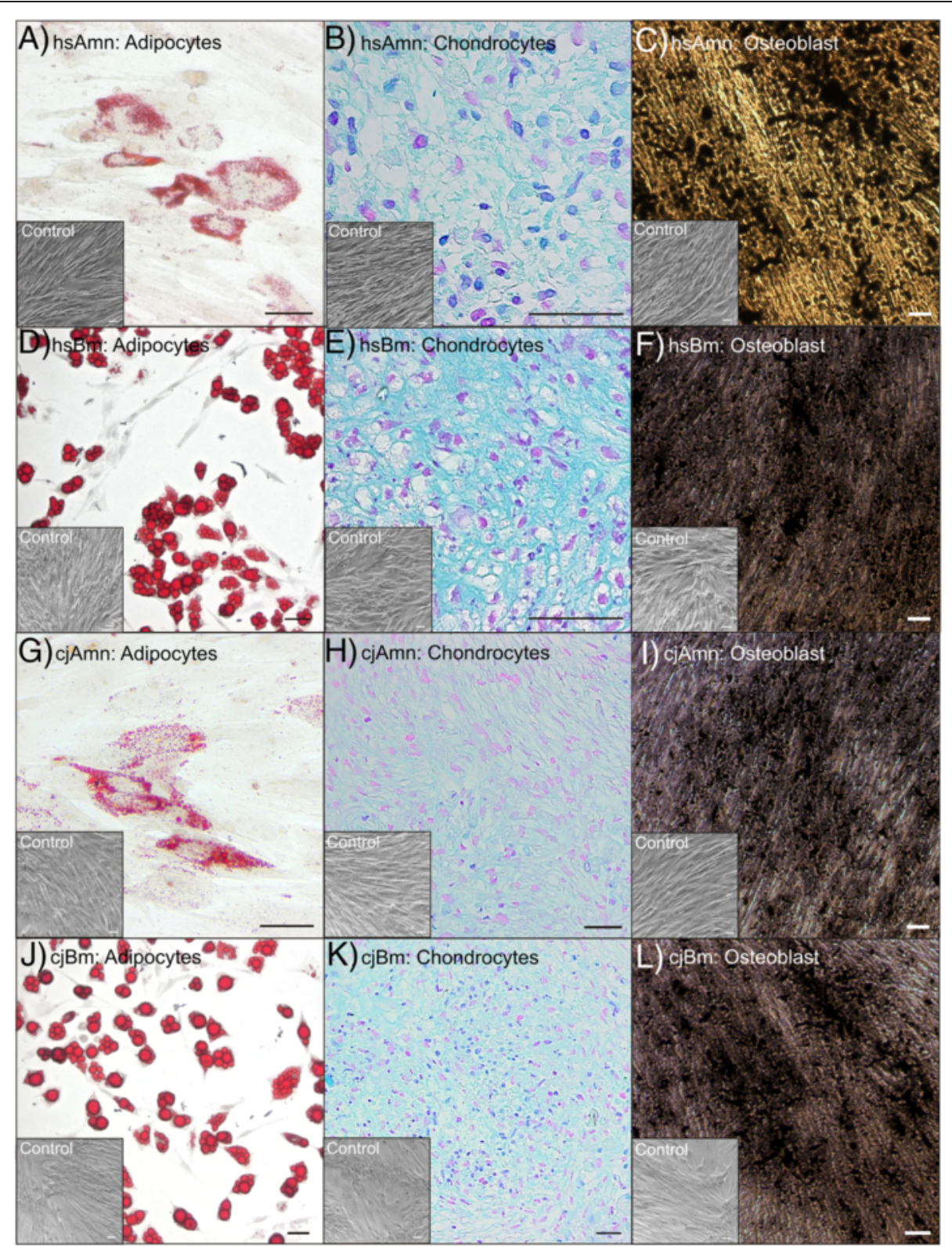

Fig. 6 Differentiation potential of human and marmoset MSCs of different origin. MSCs were differentiated into adipogenic $\mathbf{a}, \mathbf{d}, \mathbf{g}, \mathbf{j}$ (Oil Red O), chondrogenic $\mathbf{b}, \mathbf{e}, \mathbf{h}, \mathbf{k}$ (Alcian Blue), and osteogenic $\mathbf{c}, \mathbf{f}, \mathbf{i}, \mathbf{I}$ (Von Kossa) directions. Cells cultured in regular culture medium represent the negative control. During adipogenic differentiation, bone marrow samples of both species formed visually larger lipid vacuoles in comparison with amnion-derived cells $\mathbf{d}, \mathbf{j}$. Human amnion and human bone marrow samples showed higher visual intensity of Alcian blue staining $\mathbf{b}$, $\mathbf{e}$ Osteogenic potential was visually the same in all studied samples $\mathbf{c}, \mathbf{f}, \mathbf{i}, \mathbf{l}$. Scale bar $=50 \mu \mathrm{m}$

\section{MSC characteristics by surface markers}

CD73 and CD105 are generally accepted mesenchymal markers. CD73 (ecto-5' -nucleotidase) is additionally found on the surface of human $\mathrm{T}$ and B lymphocytes, facilitating in this case lymphocyte development and function [26]. CD105 (endoglin) is a type I homodimeric transmembrane glycoprotein and a key recognition structure in cellular adhesion, expressed primarily on vascular endothelial cells, chondrocytes, and syncytiotrophoblasts of term placenta, suggesting a critical role for endoglin in the binding of endothelial cells to integrins and other RGD receptors [27]. The number of $\mathrm{CD}^{+} 3^{+}$and $\mathrm{CD}_{105^{+}}$cells did not change significantly in long-term culture in both species and origins except for human bone marrow MSCs in passage 12 due to senescence. Other groups report that CD73 and CD105 levels 
in human bone marrow MSCs decrease significantly over time [28], which might be due to different long-term culture conditions.

\section{Quantitative PCR analysis of MSC markers}

Additional commonly accepted MSC markers displayed similarities and differences between the species and cellular origins. CD90 (Thy-1), usually expressed in MSCs but also in hematopoietic stem cells and fibroblasts, neurons, and activated endothelial cells [27, 29], was slightly downregulated in amnion MSC samples and upregulated in bone marrow MSC samples of both studied species, which corresponds to the other results [30].

CD44 (hyaluronic acid receptor) is a cancer stem cell marker and a potential pluripotency marker involved in cell-matrix interaction, homing, adhesion, matrix assembly, and apoptosis resistance [27, 31]. CD44 expression was significantly elevated in human amnion cells, but was barely expressed in all other studied MSC samples of both species, which is in accordance with Kanda et al. [30] but was not confirmed by Wagner et al. [28]. We speculate that these differences are due to different methodological approaches (quantitative PCR vs. FACS).

CD166 is a widely used as a MSC marker with multiple functions such as cell-cell interactions, migration and homing, neural development, hematopoiesis, immune response, and tumor progression [27, 32]. In our study, CD166 levels are generally significantly higher in bone marrow MSCs due to their role in hematopoiesis, but in general significantly lower in the marmoset, which is a species-specific difference.

CD106 is a cell surface sialoglycoprotein connected with homing, migration, and adhesion of cultured cells $[27,33,34]$ and a controversial history of presence and absence in the literature $[9,12]$. In our study, levels of CD106 in the nonhuman primate were generally significantly higher in comparison with human samples, a species-specific difference which could be explained by the immunomodulatory role of this molecule in a naturally chimeric animal like $C$. jacchus.

\section{MHC class I expression}

A major difference of bone marrow and amnion MSCs is their lack of MHC class I molecules on the surface, making them perfect candidates for potential clinical application owing to reduced immune responses during allogeneic transplantations $[25,35]$. This potential could be confirmed in our study for human and marmoset, where all bone marrow MSCs displayed high MHC class I levels from passage 3 onwards. It should be mentioned that MSCs also display other immunosuppressing strategies than MHC class I suppression [36], such as suppression of $\mathrm{CD}^{+}$and $\mathrm{CD}^{+} \mathrm{T}$ lymphocyte proliferation by the arrest anergy of $\mathrm{T}$ cells in the G0/G1 phase of the cell cycle [37]. Furthermore, and marmoset specific, we found a significant reduction of $\beta 2 \mathrm{~m}$ molecules, which might be explained by the superior immune adaptation of the marmoset as a monoplacental animal with chimeric features. Some authors suggest that this tolerance is primarily due to tryptophan catabolizing enzyme indoleamine 2,3-dioxygenase (IDO) and HLA-G molecules binding to two major inhibitory natural killer (NK) receptors, killer-cell immunoglobulin-like receptors KIR1 and KIR2, thus inhibiting NK killing [25, 38, 39]. For the future it would be interesting to investigate whether bone marrow and amnion MSCs generally utilize different or synergistic strategies to evade the immune responses and whether the reduced $\beta 2 \mathrm{~m}$ expression in the marmoset can also be found in other tissues.

\section{Presence of pluripotency markers}

There is much debate about the presence or absence of pluripotency marker genes in MSCs in general $[12,14,40-42]$. In our study, the key player (Oct-4A) was clearly present during early passaging but decreased, as expected, over time in all MSC types. In accordance with this, bisulfite sequencing of the Oct-4 promoter region showed high heterogeneity in primary cultures of all studied cell types. We speculate from these observations that there might exist a small population of cells with a tendency for pluripotency in primary MSC cultures decreasing rapidly owing to suboptimal culture conditions. Sox2 and Nanog were expressed significantly higher in the placental samples in comparison with the bone marrow [9], whereas other groups showed decreased expression in middle and later passages of chorion MSCs [43]. In our study, detectable levels of Nanog were found in both human and nonhuman primate, remaining surprisingly constant over passaging except for the human bone marrow samples owing to the mentioned senescence.

Presence of Sox2 is also reported controversially [43], but decreased in our study significantly over time in cells of both species and cellular origins. However, Sox 2 expression was significantly lower in marmoset MSCs than in human, which is not reflected in the literature and might be a specific difference between the species. Interestingly, Lin28A expression, a factor which is found in early embryogenesis, in primordial germ cells, in ESCs, and also in some adult tissues [44], was significantly higher in marmoset samples than in human. Presence of Lin28A was shown to have an impact on reprogramming efficiency in human and is subsequently required for the stable expansion of reprogrammed cells in human [45] and in marmoset [46] but is not expressed in human somatic cell lines [47]. c-Myc and Klf4 induce transcriptional regulation and have a great impact on MSC differentiation. Additionally, Klf4 has been shown to regulate MSC transcriptional activity and maintain cells in the 
undifferentiated state $[48,49]$. In our experiments, Klf4 levels were below skin controls in all cell types and also $c-M y c$ expression was very weak in all MSC cultures.

In summary, indications of "stemness" were observed in early passages of both amnion and bone marrowderived MSCs from human and marmoset. However, the expression level of Sox2 was significantly lower and expression of Lin28A was significantly higher in the nonhuman primate.

\section{Conclusions}

Application of stem cell therapy in treating various autoimmune and neurodegenerative diseases is rapidly progressing. Since the usage of highly pluripotent ESCs and iPSCs in clinics is exceedingly complicated by legislative, ethical, and safety issues, numerous studies are focused on application of MSCs and hematopoietic stem cells as a therapeutic tool being the most feasible approach for the purposes of regenerative medicine. However, adequate preclinical animal models are required to study long-term outcome in terms of graft rejection and efficiency of cellular therapies.

Our major findings in this manuscript are the following: human and marmoset cells share most common MSC features, and thus a small nonhuman primate common marmoset proves to be a valid preclinical model also in the field of MSC research; amnion MSCs of both species have higher proliferation activity in comparison with bone marrow MSCs, thus making them superior candidates for expansion; amnion MSCs of both species display low MHC class I expression in early passages, whereas bone marrow MSCs have significantly higher MHC class I levels from the very beginning, indicating a potential disadvantage in the case of transplantation; and all studied types of MSCs express certain levels of pluripotency markers, with differences in Lin28 and Sox 2 expression between the species. Taken together with findings on demethylated Oct-4 promoter regions, we speculate that a small subpopulation of still pluripotent cells might be present in early passages. The developmental origin of these cells remains unclear and would require further investigation. In summary, we believe that the potential of placenta-derived MSCs is greatly underrated, particularly in terms of pluripotency and immunology. If this postulated pluripotent amnion cell subpopulation could be stabilized by cultural methods, the genetic and technical problems of virally induced pluripotent cells could be easily overcome in the future with a cell source that can be obtained noninvasively and is patient specific.

\section{Abbreviations}

ALCAM: Activated leukocyte cell adhesion molecule; CD: Cluster of differentiation; CeRA: Centre of Reproductive Medicine and Andrology; $\mathrm{ddH}_{2} \mathrm{O}$ : Double-distilled water; DMEM: Dulbecco's Modified Eagle Medium; EDTA: Ethylenediamine tetracetic acid; ELISA: Enzyme-linked immunosorbent assay; ESC: Embryonic stem cell; FACS: Fluorescence-activated cell sorting; FCS: Fetal calf serum; FGF: Fibroblast growth factor; HLA: Human leukocyte antigen; IDO: Indoleamine 2,3-dioxygenase; IHC: Immunohistochemistry; iPSC: Induced pluripotent stem cell; KIR: killer-cell immunoglobulin-like receptor; MHC: Major histocompatibility complex; MSC: Multipotent stromal cell; MTT: 3-(4,5-Dimethylthiazol-2-yl)-2,5-diphenyltetrazolium bromide; NK: Natural killer; PBS: Phosphate-buffered saline; sGAG: Sulfated glycosaminoglycan; VCAM: Vascular cell adhesion molecule;

ß2m: Beta-2-microglobulin.

\section{Competing interests}

The authors declare that they have no competing interests.

\section{Authors' contributions}

OP designed the study, carried out cell culture maintenance, performed molecular genetic studies, implemented statistical analysis, and drafted the manuscript. DP assisted in cell culture maintenance, performed the metabolic activity test, carried out and analyzed bisulfite sequencing, and drafted the manuscript. A-LN carried out titration and efficiency of primers for real-time PCR and helped to revise the manuscript. AH prepared and provided human bone marrow stem cells for the study and revised the manuscript. RB gave approval for the study design, revised the data and manuscript, and approved the final version to be published. TM designed and coordinated the study, and participated in data analysis and manuscript writing. All authors read and approved the final manuscript.

\section{Acknowledgements}

The authors thank Kirsten Elger for excellent technical support. Their gratitude also includes Prof. Stefan Schlatt and the CeRA for providing us with material from the common marmoset and Dr M Imamura and Dr YZ Lin for methodical help with methylation profiling.

\section{Author details}

${ }^{1}$ Institute for Transfusion Medicine, Hannover Medical School, Carl-Neuberg-Straße 1, 30625 Hannover, Germany. ${ }^{2}$ Department of Orthopaedic Surgery, Hannover Medical School, Anna-von-Borries-Straße 1-7, 30625 Hannover, Germany.

Received: 23 February 2015 Revised: 24 February 2015

Accepted: 5 August 2015

Published online: 22 August 2015

\section{References}

1. Macias MI, Grande J, Moreno A, Dominguez I, Bornstein R, Flores Al. Isolation and characterization of true mesenchymal stem cells derived from human term decidua capable of multilineage differentiation into all 3 embryonic layers. Am J Obstet Gynecol. 2010;203:495.e9-e23.

2. Dominici M, Le Blanc K, Mueller I, Slaper-Cortenbach I, Marini F, Krause D, et al. Minimal criteria for defining multipotent mesenchymal stromal cells. The International Society for Cellular Therapy position statement. Cytotherapy. 2006;8:315-7.

3. Mafi R, Hindocha S, Mafi P, Griffin M, Khan WS. Sources of adult mesenchymal stem cells applicable for musculoskeletal applications - a systematic review of the literature. Open Orthop J. 2011;5:242-8.

4. Barlow S, Brooke G, Chatterjee K, Price G, Pelekanos R, Rossetti T, et al. Comparison of human placenta- and bone marrow-derived multipotent mesenchymal stem cells. Stem Cells Dev. 2008;17:1095-107.

5. Wegmeyer H, Broske AM, Leddin M, Kuentzer K, Nisslbeck AK, Hupfeld J, et al. Mesenchymal stromal cell characteristics vary depending on their origin. Stem Cells Dev. 2013;22:2606-18.

6. Jaramillo-Ferrada PA, Wolvetang EJ, Cooper-White JJ. Differential mesengenic potential and expression of stem cell-fate modulators in mesenchymal stromal cells from human-term placenta and bone marrow. J Cell Physiol. 2012;227:3234-42.

7. Hass R, Kasper C, Bohm S, Jacobs R. Different populations and sources of human mesenchymal stem cells (MSC): a comparison of adult and neonatal tissue-derived MSC. Cell Commun Signal. 2011;9:12.

8. Yoshizawa RS. Review: Public perspectives on the utilization of human placentas in scientific research and medicine. Placenta. 2013;34:9-13. 
9. Sabapathy $V$, Ravi S, Srivastava $V$, Srivastava A, Kumar S. Long-term cultured human term placenta-derived mesenchymal stem cells of maternal origin displays plasticity. Stem Cells Int. 2012;174328.

10. Weiss ML, Troyer DL. Stem cells in the umbilical cord. Stem Cell Rev. 2006;2:155-62.

11. Semenov OV, Koestenbauer S, Riegel M, Zech N, Zimmermann R, Zisch AH, et al. Multipotent mesenchymal stem cells from human placenta: critical parameters for isolation and maintenance of stemness after isolation. Am J Obstet Gynecol. 2010;202:193.e1-e13.

12. Sarugaser R, Lickorish D, Baksh D, Hosseini MM, Davies JE. Human umbilical cord perivascular (HUCPV) cells: a source of mesenchymal progenitors. Stem Cells. 2005;23:220-9.

13. Leeb C, Jurga M, McGuckin C, Moriggl R, Kenner L. Promising new sources for pluripotent stem cells. Stem Cell Rev. 2010;6:15-26.

14. Koike C, Zhou K, Takeda Y, Fathy M, Okabe M, Yoshida T, et al. Characterization of amniotic stem cells. Cell Reprogram. 2014;16:298-305.

15. Mansfield K. Marmoset models commonly used in biomedical research. Comp Med. 2003;53:383-92.

16. Sasaki E, Hanazawa K, Kurita R, Akatsuka A, Yoshizaki T, Ishii H, et al. Establishment of novel embryonic stem cell lines derived from the common marmoset (Callithrix jacchus). Stem Cells. 2005;23:1304-13.

17. Mueller T, Fleischmann G, Horn P, Sasaki E, Behr R. A novel primate ES cell line from the common marmoset (Callithrix jacchus) exhibits germ cell development in vitro. J Stem Cells Regen Med. 2007;2:81-2.

18. Wiedemann A, Hemmer K, Bernemann I, Gohring G, Pogozhykh O, Figueiredo C, et al. Induced pluripotent stem cells generated from adult bone marrow-derived cells of the nonhuman primate (Callithrix jacchus) using a novel quad-cistronic and excisable lentiviral vector. Cell Reprogram. 2012;14:485-96.

19. Wu Y, Mishra A, Qiu Z, Farnsworth S, Tardif SD, Hornsby PJ. Nonhuman primate induced pluripotent stem cells in regenerative medicine. Stem Cells Int. 2012;2012:767195.

20. Schack LM, Noack S, Weist $R$, Jagodzinski M, Krettek C, Buettner M, et al. Analysis of surface protein expression in human bone marrow stromal cells: new aspects of culture-induced changes, inter-donor differences and intracellular expression. Stem Cells Dev. 2013;22:3226-35.

21. Lin ZY, Imamura M, Sano C, Nakajima R, Suzuki T, Yamadera R, et al. Molecular signatures to define spermatogenic cells in common marmoset (Callithrix jacchus). Reproduction. 2012;143:597-609.

22. Moon JH, Lee JR, Jee BC, Suh CS, Kim SH, Lim HJ, et al. Successful vitrification of human amnion-derived mesenchymal stem cells. Hum Reprod. 2008;23:1760-70

23. Batlle R, Alba-Castellon L, Loubat-Casanovas J, Armenteros E, Franci C, Stanisavljevic J, et al. Snail1 controls TGF-beta responsiveness and differentiation of mesenchymal stem cells. Oncogene. 2013;32:3381-9.

24. Kim Y, Kim H, Cho H, Bae Y, Suh K, Jung J. Direct comparison of human mesenchymal stem cells derived from adipose tissues and bone marrow in mediating neovascularization in response to vascular ischemia. Cell Physiol Biochem. 2007;20:867-76.

25. Deuse T, Stubbendorff M, Tang-Quan K, Phillips N, Kay MA, Eiermann T, et al. Immunogenicity and immunomodulatory properties of umbilical cord lining mesenchymal stem cells. Cell Transplant. 2011;20:655-67.

26. Yamashita $Y$, Hooker SW, Jiang H, Laurent AB, Resta R, Khare K, et al. CD73 expression and fyn-dependent signaling on murine lymphocytes. Eur Immunol. 1998;28:2981-90.

27. Shiffman MAGA, Bassetto F, editors. Stem cells in aesthetic procedures: art, science, and clinical techniques. Heidelberg: Springer; 2014.

28. Wagner W, Horn P, Castoldi M, Diehlmann A, Bork S, Saffrich R, et al. Replicative senescence of mesenchymal stem cells: a continuous and organized process. PLoS One. 2008;3, e2213.

29. Kisselbach L, Merges M, Bossie A, Boyd A. CD90 Expression on human primary cells and elimination of contaminating fibroblasts from cell cultures. Cytotechnology. 2009;59:31-44.

30. Kanda A, Sotomaru Y, Nobukiyo A, Yamaoka E, Hiyama E. Characterization of common marmoset (Callithrix jacchus) bone marrow-derived mesenchymal stem cells. Folia Histochem Cytobiol. 2013;51:292-9.

31. Zoller M. CD44: can a cancer-initiating cell profit from an abundantly expressed molecule? Nat Rev Cancer. 2011;11:254-67.

32. Swart GW. Activated leukocyte cell adhesion molecule (CD166/ALCAM): developmental and mechanistic aspects of cell clustering and cell migration. Eur J Cell Biol. 2002;81:313-21.
33. Jung EM, Kwon O, Kwon KS, Cho YS, Rhee SK, Min JK, et al. Evidences for correlation between the reduced VCAM-1 expression and hyaluronan synthesis during cellular senescence of human mesenchymal stem cells. Biochem Biophys Res Commun. 2011:404:463-9.

34. Abumaree MH, Al Jumah MA, Kalionis B, Jawdat D, Al Khaldi A, AlTalabani AA et al. Phenotypic and functional characterization of mesenchymal stem cells from chorionic villi of human term placenta. Stem Cell Rev. 2013;9:16-31.

35. Bacenkova D, Rosocha J, Tothova T, Rosocha L, Sarissky M. Isolation and basic characterization of human term amnion and chorion mesenchymal stromal cells. Cytotherapy. 2011;13:1047-56.

36. Le Blanc K, Tammik C, Rosendahl K, Zetterberg E, Ringden O. HLA expression and immunologic properties of differentiated and undifferentiated mesenchymal stem cells. Exp Hematol. 2003:31:890-6.

37. Benvenuto F, Ferrari S, Gerdoni E, Gualandi F, Frassoni F, Pistoia V, et al. Human mesenchymal stem cells promote survival of $T$ cells in a quiescent state. Stem Cells. 2007;25:1753-60.

38. Averdam A, Kuhl H, Sontag M, Becker T, Hughes AL, Reinhardt R, et al. Genomics and diversity of the common marmoset monkey NK complex. J Immunol. 2007;178:7151-61.

39. Gomez-Lozano N, de Pablo R, Puente S, Vilches C. Recognition of HLA-G by the NK cell receptor KIR2DL4 is not essential for human reproduction. Eur J Immunol. 2003:33:639-44.

40. Yannarelli G, Pacienza N, Cuniberti L, Medin J, Davies J, Keating A. Brief report: The potential role of epigenetics on multipotent cell differentiation capacity of mesenchymal stromal cells. Stem Cells. 2013;31:215-20.

41. Moschidou D, Mukherjee S, Blundell MP, Drews K, Jones GN, Abdulrazzak H, et al. Valproic acid confers functional pluripotency to human amniotic fluid stem cells in a transgene-free approach. Mol Ther. 2012;20:1953-67.

42. Moschidou D, Mukherjee S, Blundell MP, Jones GN, Atala AJ, Thrasher AJ, et al. Human mid-trimester amniotic fluid stem cells cultured under embryonic stem cell conditions with valproic acid acquire pluripotent characteristics. Stem Cells Dev. 2013;22:444-58.

43. Fariha MM, Chua KH, Tan GC, Tan AE, Hayati AR. Human chorion-derived stem cells: changes in stem cell properties during serial passage. Cytotherapy. 2011:13:582-93.

44. Aeckerle N, Drummer C, Debowski K, Viebahn C, Behr R. Primordial germ cell development in the marmoset monkey as revealed by pluripotency factor expression: suggestion of a novel model of embryonic germ cell translocation. Mol Hum Reprod. 2015;21:66-80.

45. Yu J, Vodyanik MA, Smuga-Otto K, Antosiewicz-Bourget J, Frane JL, Tian S, et al. Induced pluripotent stem cell lines derived from human somatic cells. Science. 2007:318:1917-20.

46. Tomioka I, Takahashi T, Shimada A, Yoshioka K, Sasaki E. Birth of common marmoset (Callithrix jacchus) offspring derived from in vitro-matured oocytes in chemically defined medium. Theriogenology. 2012;78:1487-93.

47. Vogt EJ, Meglicki M, Hartung Kl, Borsuk E, Behr R. Importance of the pluripotency factor LIN28 in the mammalian nucleolus during early embryonic development. Development. 2012;139:4514-23.

48. Roson-Burgo B, Sanchez-Guijo F, Del Canizo C, De Las Rivas J. Transcriptomic portrait of human mesenchymal stromal/stem cells isolated from bone marrow and placenta. BMC Genomics. 2014;15:910

49. Fan W, Crawford R, Xiao Y. The ratio of VEGF/PEDF expression in bone marrow mesenchymal stem cells regulates neovascularization. Differentiation. 2011:81:181-91.

\section{Submit your next manuscript to BioMed Central and take full advantage of:}

- Convenient online submission

- Thorough peer review

- No space constraints or color figure charges

- Immediate publication on acceptance

- Inclusion in PubMed, CAS, Scopus and Google Scholar

- Research which is freely available for redistribution 